\title{
COMPARATIVE STUDY ON ANAEROBIC DEGRADATION PROCESSES OF PRESSED LIQUID FRACTION OF ORGANIC SOLID WASTE
}

\author{
TAMÁs RÓZSENBERSZKI*1 ${ }^{*}$ LÁSZLÓ KOÓK ${ }^{1}$, PÉTER BAKONYI ${ }^{1}$, NÁNDOR NEMESTÓTHY ${ }^{1}$, AND \\ KATALIN BÉLAFI-BAKÓ ${ }^{1}$
}
${ }^{1}$ Research Centre for Biochemical, Environmental and Chemical Engineering, University of Pannonia, Egyetem u. 10, Veszprém, 8200, HUNGARY

\begin{abstract}
Anaerobic degradation processes: anaerobic digestion (biogasification), biohydrogen fermentation (dark) and microbial fuel cells were applied to treat the organic fraction of a municipal solid waste. The processes were compared based on their ability of energy recovery and Chemical Oxygen Demand reduction.
\end{abstract}

Keywords: organic waste, anaerobic biodegradation, microbial fuel cell, energy recovery, process comparison

\section{Introduction, background}

\subsection{Waste challenges}

The world population has more than doubled over the last 60 years. Due to this growing tendency and urbanization the world's energy consumption and value of waste generation present us with major challenges with sustainable development in mind. Furthermore, it is obvious that waste treatment is one of the most critical global issue, because it has significant impacts for the health, local and global environment and economy [1]. According to the World Bank Group, 2.01 billion tonnes of municipal solid waste (MSW) around the world are generated annually, and at least one third of that is not managed environmentally acceptable manner [2]. The average waste generated per person per day is 0.74 kilogram, but there are significant differences between data by countries, from 0.11 to 4.54 kilograms. Actually, high-income countries only cover for 16 percent of world's community, although generate around 34 percent of the world's waste. Based on their estimation global waste will grow to 2.2 billion tonnes by 2025 and to 3.40 billion tonnes by 2050 [1,2]. These facts make solid waste management (SWM) is a challenging task for decision-makers, who are required to provide essential waste collection and disposal services, generally under increasingly stringent budgetary pressures and regulatory requirements [3].

\subsection{Biowaste}

MSW typically consists of food waste, paper, glass, metals, plastics, textiles, etc. In developed countries the

\footnotetext{
*Correspondence: rozsenberszki.tamas@uni-pannon.hu
}

amount of paper and plastics are relatively higher than the case of developing countries, where the main part of MSW is organic waste [4]. There are variations in the characteristics of MSW across the world, but remarkable part of the municipal solid waste is containing biodegradable organic components (world average: 46\%) [1, 5]. There is a variety of treatment alternatives that provide not only disposal of this organic part but also energy recovery options. This section is going to present some anaerobic biodegradation processes so the following part of this section will focus on the organic waste.

Based on the data of the Food and Agriculture Organization roughly one-third of food produced for human consumption is lost or wasted globally, which amounts more than 1.2 billion tons per year $[6,7]$. In the European Union, more than 85 million tonnes of food waste are generated per year with associated costs estimated at around 143 billion euros [7, 8]. According to San Martin et al. vegetable waste deposited as landfill could be reduced to $30 \%$ [9]. Some studies in this topic have indicated that vegetable waste has a remarkable potential for use as a raw material for animal feed. For example, Garcia at al. concluded that some part of various organic wastes (meat, fish, restaurant and household waste, fruit and vegetable) was possible to use in animal feed formulations [10].

\subsection{Treatment processes for the municipal solid waste}

It is important to notice the reduction of the waste problem should be started at the prevention and reduce the level of the overconsumption. However, in our consumer 


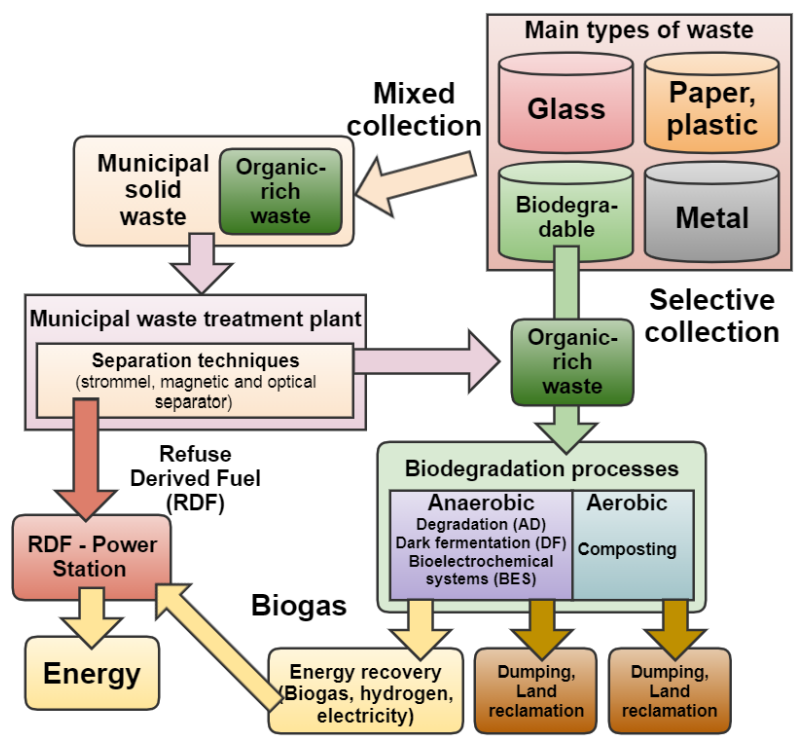

Figure 1: Schematic illustration of an example how to integrate bioprocesses in the MBT for the efficient MSW treatment

society today the market sphere is not interested in the reduction of the consumption, because the drop of consumption means less profit. It is still common to dump the treated or not treated waste, instead of produce valuable products to sell commercially or for own use, possibly recover energy from them [11]. Waste dumping seems convenient and cheap solution but in the long term it is unprofitable and unsustainable technique. As long as this practice is followed, efforts should be made to continue the development such research that can minimize the negative effects of excess use. In the case of society it is an important task to focus on how can expand the environmental friendly thinking already from the basic education.

Fig. 1 presents the main treating processes of the MSW. In most cases the aim is to reduce the toxicity of the waste in addition energy generation and in the case of composting soil conditioners could be recovered. The most unpreferable technique of them is the waste dumping without gas collection or recovery [12]. Somewhat better choice is the landfilling which is currently the main technological facility applied to treat and dispose MSW worldwide. But this represents still low level based on the waste treatment hierarchy $[13,14]$. Although landfill seems a cheap alternative, it can pollute the surrounding area (air, soil and also the water). Over the years the collected landfill gas has limited use (no more than $60 \%$ methane content) [15]. Landfill gas with low $\mathrm{CH}_{4}$ content (low calorific gas) is difficult to directly burn so it does not seem to be the best solution [15]. The thermal processes can reduce significantly the volume of the waste but the cost of the plant installation and operation is relatively high. Moreover the flue gas and ash resulted need further treatments from environmental point of view [12].

\subsection{Biodegradation processes for waste treat- ment}

In the case of aerobic biological methods composting can stabilize the organic waste and could produce soil conditioners but the bound energy of the waste cannot be utilized. On the other hand it needs relatively large area and longer time to get valuable products [4]. Nevertheless, due to the comparatively simple operation it is still a widely used technique for the treatment of organic rich fraction.

Staying on the biological line the anaerobic digestion (AD) or biogasification is operating under anaerobic conditions. Consequently, organic matter is degraded by a microbial community consisting of bacteria in the absence of oxygen and generating methane, carbon dioxide, and useable residue without any exothermic heat. It seems advantageous to choose AD because the biogas (around $60-70 \%$ methane content) and biomethane are economically more valuable products than compost or the landfill gas. In addition the residue resulted by an anaerobic process integrated with an aerobic stage has the same quality parameters like compost [16].

Before the installation of an AD system it is necessary to focus on the typical waste composition for the area because it can show significant diversity. It is not a simple process but there are modelling possibilities. According to Cermiato et al. these combined bioprocesses including $\mathrm{AD}$ and digestate composting resulted higher performance than those applied pure composting [16]. In addition AD usually causes lower environmental impact than composting because it can fulfill two levels of the waste hierarchy at the same time. Actually, the biodegradable waste (e.g., food loss, green waste) can be considered as a type of sustainable resources. In this view through $\mathrm{AD}$ process the energy is generated by a renewable source (biowaste) thus avoiding the energy which produced from conventional or fossil sources. Generally around $120 \mathrm{~m}^{3}$ of biogas can be produced with a total electricity yield of about $250 \mathrm{kWh}$ and a net electricity yield of $204 \mathrm{kWh}$ from one ton of biowaste [16].

Fei et al. carried out life cycle assessment on MSW treatment technologies. Results showed that the mechanical-biological treatment (MBT) had higher efficiency than landfill and incineration [17]. According to the life cycle assessment the worst option was the raw land filling. The incineration had a higher energy efficiency ( $20.5 \%$ energy recovery) but in this case the large amount of fly ash and exhaust treatment caused more environmental impacts. It seemed the MBT had the highest energy efficiency $(38.5 \%)$ when it combined with biogas purification method. Montejo et al. found similar results about connection MBT and AD [18]. In addition, MBT had less environmental impacts and relatively good stability for the changing composition of MSW. On the other hand, MBT had weak economy performance and required economy support policy. 
Table 1: Main types of the municipal solid waste treatment [12]

\begin{tabular}{l|ll|lll|ll}
\hline Treatment process & \multicolumn{3}{|c|}{ Thermal treatment } & \multicolumn{2}{c}{ Biological treatment } & \multicolumn{2}{c}{ Landfilling } \\
\hline Method & Incineration Pyrolysis Gasification & $\begin{array}{l}\text { Refuse } \\
\text { derived } \\
\text { fuel }\end{array}$ & $\begin{array}{l}\text { Anaerobic Composting } \\
\text { digestion }\end{array}$ & $\begin{array}{l}\text { Landfill } \\
\text { with gas } \\
\text { recovery }\end{array}$ & $\begin{array}{l}\text { Landfill } \\
\text { without gas } \\
\text { recovery }\end{array}$ \\
\hline Product & $\begin{array}{l}\text { Heat, } \\
\text { Power }\end{array}$ & $\begin{array}{l}\text { Gas, Oil, Syngas } \\
\text { Charcoal }\end{array}$ & $\begin{array}{l}\text { Heat, } \\
\text { Power }\end{array}$ & Biogas & Compost & $\begin{array}{l}\text { Landfill } \\
\text { gas }\end{array}$ & - \\
\hline Energy recovery & yes & yes $\quad$ yes & yes & yes & no & yes & no \\
\hline
\end{tabular}

Table 2: Summary of the results coming from the sample utilization by various anaerobic degradation methods

\begin{tabular}{lccc}
\hline Process & AD & HDF & MFC \\
\hline Amount of sample $\left(\mathrm{cm}^{\mathbf{3}}\right)$ & 25 & 25 & 25 \\
Volume of inoculum $\left(\mathrm{cm}^{\mathbf{3}}\right)$ & 25 & 25 & 25 \\
Valuable product & methane $^{*}\left(299 \mathrm{~cm}^{3}\right)$ & hydrogen* $\left(91 \mathrm{~cm}^{3}\right)$ & electricity \\
Theoretical energy recovery** & $11.7 \mathrm{~kJ}$ & $1.14 \mathrm{~kJ}$ & $0.031 \mathrm{~kJ}$ \\
Particular energy recovery*** & $4.1 \mathrm{~kJ}$ & $0.8 \mathrm{~kJ}$ & $0.031 \mathrm{~kJ}$ \\
Operation time (day) & 40 & 2 & 30 \\
Reduction of COD & medium & low & high \\
\hline \multicolumn{4}{c}{ * Reffering to standard temperature and pressure } \\
& $* * *$ Reffering to maximal utilization rate with no losses \\
\end{tabular}

\section{MBT with other anaerobic processes}

In this subsection a particular example for an integrated anaerobic treatment is presented. A special sample coming from the organic fraction of a municipal solid waste was studied [19-21]. Actually it was concentrated organic rich wastewater produced from mixed collected solid waste by pressing in a MBT plant (Királyszentistván). During the MBT separation technology a biodegradable fraction generated called biofraction utilized by the Plant's biological stabilizing hall (compostation) to treat it before the dumping (Fig. 1). The aim was to utilize the sample (before the composting process) with different anaerobic biodegradation methods to reduce the organic content and produce energy or valuable products (hydrogen, methane). Thus the volume of waste will decrease (from the aspect of environmental protection) whilst the energy content of the waste can be exploited.

In the first stage of experimental work the sample was characterized by analytical methods. It has high Chemical Oxygen Demand (COD) and Biochemical Oxygen Demand (BOD) content $111 \mathrm{~g} \mathrm{~L}^{-1}$ and $61 \mathrm{~g} \mathrm{~L}^{-1}$ respectively, which parameters are promising for the biological treatment used. The various methods were the anaerobic digestion (AD), biohydrogen dark fermentation (HDF) and a kind of bioelectrochemical system (BES): the microbial fuel cell (MFC). As an inoculum mesophilic sludge from a biogas plant was used in each cases. The details about the materials and methods used were described in our previous studies [19-21].

Based on the experiments presented in Table 2, AD seems to be the most preferable method to integrate in the MBT process. It resulted high cumulative energy recov- ery (11.7 kJ) and medium COD removal, but it needs long time for the degradation mechanism (methanogenic pathways). HDF lasted a few days and during the process 1.14 $\mathrm{kJ}$ cumulative energy was generated however the COD removal was in low level, thus the effluent needed further treatment. There were successful experiments where AD and MFC were combined to treat the COD of the effluent from HDF. On the other hand HDF is a promising method if the desired final product is the hydrogen which is otherwise an encouraging energy sources for the future [22]. During the two chambered MFC process direct electrical energy was generated, but it had lot of limitation factors including type and structure of the system, electrode materials used, type of membrane, external and internal resistant, operation and adaptation period, biofouling, etc. Our results showed that if MFC system was integrated to $\mathrm{HDF}$ or AD the system's energy recovery (coulombic efficiency) and COD removal could be higher.

\section{Conclusion}

In many countries the waste management still does not get enough attention. The technologies of the biowaste treatment are already known just need to optimize for the characteristics of the waste streams in that area. Decision makers should choose the sustainable and low risk ways for the environment. The results of our and other experimental works showed that MBT combined with anaerobic degradation processes could be an acceptable way to the clean and economical treatment in the case of significant amount of mixed collected MSW. However, selectively collected biowaste has even more potential to maximize the recovery of their energy content. Depending on the composition of the waste it may be advantageous to 
integrate the different treatment methods to improve for an appropriate level of the effectiveness.

\section{Acknowledgements}

The authors thank for the financial support provided by the Széchenyi 2020 Programme under the project EFOP3.6.1-16-2016-00015, and by the Excellence of Strategic $\mathrm{R}+\mathrm{D}$ Workshops under the project GINOP-2.3.215-2016-00016 entitled "Development of modular, mobile water treatment systems and wastewater treatment technologies based at the University of Pannonia to enhance growing dynamic exportation from Hungary between 2016 and 2020".

\section{REFERENCES}

[1] Hoornweg, D.; Bhada-Tata, P.: What a Waste: A Global Review of Solid Waste Management. Urban Development Series. Knowledge Papers No. 15, World Bank, 2012, 1. https://openknowledge.worldbank.org

[2] Kaza, S.; Yao, L.C.; Bhada-Tata, P.; Van Woerden, F.: What a Waste 2.0: A Global Snapshot of Solid Waste Management to 2050. World Bank Publications, 2018. DOI: 10.1596/978-1-4648-1329-0

[3] Roberts, K.P.; Turner, D.A.; Coello, J.; Stringfellow, A.M.; Bello, I.A.; Powrie, W.; Watson, G.V.R.: SWIMS: A dynamic life cycle-based optimisation and decision support tool for solid waste management. J. Clean. Prod., 2018, 196, 547-63 DOI: 10.1016/j.jclepro.2018.05.265

[4] Logan, M.; Visvanathan, C.: Management strategies for anaerobic digestate of organic fraction of municipal solid waste: Current status and future prospects. Waste Manag. Res., 2019, 37(1), 27-39 DOI: 10.1177/0734242X18816793

[5] Edjabou, M.E.; Jensen, M.B.; Götze, R.; Pivnenko, K.; Petersen, C.; Scheutz, C.; Astrup, T.F.: Municipal solid waste composition: Sampling methodology, statistical analyses, and case study evaluation. Waste Manag., 2015, 36, 12-23 DOI: 10.1016/j.wasman.2014.11.009

[6] Gustavsson, J.; Cederberg, C.: S.U.; Global Food losses and Food waste. Unep, 2011, 1. http://www.fao.org

[7] Preparatory Study on Food Waste Across EU 27, European Commission (DG ENV); Final Report, 2011. ISBN: 978-92-79-22138-5 https://ec.europa.eu

[8] Stenmarck, L.; Jensen, C.; Quested, T.; Moates, G.; Cseh, B.; Juul, S.; Parry, A.; Politano, A.; Redlingshofer, B.; Scherhaufer, S.; Silvennoinen, K.; Soethoudt, H.; Zübert, C.; Östergren, K.: FUSIONS - Estimates of European food waste levels IVL Swedish Environmental Research Institute: Stockholm, Sweden. 2016 https://www.eu-fusions.org

[9] San Martin, D.; Ramos, S.; Zufía, J.: Valorisation of food waste to produce new raw materials for animal feed. Food Chem., 2016, 198, 68-74 DOI: 10.1016/j.foodchem.2015.11.035

[10] García, A.J.; Esteban, M.B.; Márquez, M.C.; Ramos, P.: Biodegradable municipal solid waste: Characterization and potential use as animal feedstuffs. Waste Manag., 2005, 25(8), 780-787. DOI: 10.1016/j.wasman.2005.01.006

[11] Torretta, V.; Ferronato, N.; Katsoyiannis, I.A.; Tolkou, A.K.; Airoldi, M.: Novel and conventional technologies for landfill leachates treatment: A review. Sustainability, 2017, 9(1), 9 DOI: 10.3390/su9010009

[12] Kumar, A.; and Samadder, S.R.: A review on technological options of waste to energy for effective management of municipal solid waste. Waste Manag., 2017, 69, 407-422 DOI: 10.1016/j.wasman.2017.08.046

[13] Trulli, E.; Ferronato, N.; Torretta, V.; Piscitelli, M.; Masi, S.; Mancini, I.: Sustainable mechanical biological treatment of solid waste in urbanized areas with low recycling rates. Waste Manag., 2018, 71, 556-564 DOI: 10.1016/j.wasman.2017.10.018

[14] Hansen, W.; Christopher, M.; Verbuecheln, M.: EU Waste Policy and Challenges for Regional and Local Authorities, Background Paper for the Seminar on Household Waste Management, "Capacity Building on European Community's Environmental Policy", Ecological Institute for International and European Environmental Policy: Berlin, Germany, 2002. https://www.ecologic.eu

[15] Khalil, A.E.E.; Arghode, V.K.; Gupta, A.K.; Lee, S.C.: Low calorific value fuelled distributed combustion with swirl for gas turbine applications. Appl. Energy, 2012, 98, 69-78 DOI: 10.1016/j.apenergy.2012.02.074

[16] Cremiato, R.; Mastellone, M.L.; Tagliaferri, C.; Zaccariello, L.; Lettieri, P.: Environmental impact of municipal solid waste management using Life Cycle Assessment: The effect of anaerobic digestion, materials recovery and secondary fuels production. Renew. Energy, 2018, 124, 180-188 DOI: 10.1016/j.renene.2017.06.033

[17] Fei, F.; Wen, Z.; Huang, S.; De Clercq, D.: Mechanical biological treatment of municipal solid waste: Energy efficiency, environmental impact and economic feasibility analysis. J. Clean. Prod., 2018, 178, 731-739 DOI: 10.1016/j.jclepro.2018.01.060

[18] Montejo, C.; Tonini, D.; Márquez, M. del C.; Fruergaard Astrup, T.: Mechanical-biological treatment: Performance and potentials. An LCA of 8 MBT plants including waste characterization. J. Environ. Manage., 2013, 128, 661-673 DOI: 10.1016/j.jenvman.2013.05.063

[19] Rózsenberszki, T.; Koók, L.; Hutvágner, D.; Nemestóthy, N.; Bélafi-Bakó, K.; Bakonyi, P.; Kurdi, R.; Sarkady, A.: Comparison of anaerobic degradation processes for bioenergy generation from liquid fraction of pressed solid waste. 
Waste Biomass Valori., 2015, 6, 465-473 DOI: 10.1007/s12649-015-9379-y

[20] Rózsenberszki, T.; Koók, L.; Bakonyi, P.; Nemestóthy, N.; Logrońo, W.; Pérez, M.; Urquizo, G.; Recalde, C.; Kurdi, R.; Sarkady, A.: Municipal waste liquor treatment via bioelectrochemical and fermentation $\left(\mathrm{H}_{2}+\mathrm{CH}_{4}\right)$ processes: Assessment of various technological sequences. Chemosphere, 2017, 171, 692-701 DOI: 10.1016/j.chemosphere.2016.12.114

[21] Koók, L.; Rózsenberszki, T.; Nemestóthy, N.;
Bélafi-Bakó, K.; Bakonyi, P.: Bioelectrochemical treatment of municipal waste liquor in microbial fuel cells for energy valorization. $J$. Clean. Prod., 2016, 112(5), 4406-4412 DOI: 10.1016/j.jclepro.2015.06.116

[22] Hosseini, S.E.; Wahid, M.A.: Hydrogen production from renewable and sustainable energy resources: Promising green energy carrier for clean development. Renew. Sustain. Energy Rev., 2016, 57, 850 866 DOI: 10.1016/j.rser.2015.12.112 